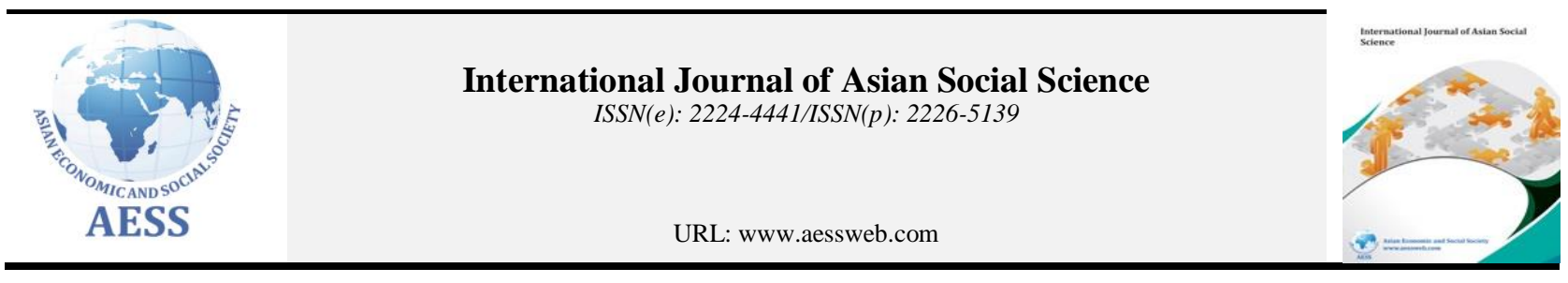

\title{
TEACHING-LEARNING MODEL OF ISLAMIC EDUCATION AT MADRASAH BASED ON MOSQUE IN SINGAPORE
}

\author{
Ishomuddin $^{1 \dagger}$--- Scanif Bin Mokhtar ${ }^{2}$ \\ ${ }^{1}$ Professor of Sociology of Islamic Society, University of Muhammadiyah Malang, Ishom \\ ${ }^{2}$ Head and Teacher of Islamic Studies, Madrasah Islamiyah Siglap, Singapore
}

\section{ABSTRACT}

The purpose of this research is (1) to know the characteristic of method in teaching-learning done by alumni of Middle East in Islamic education, (2) To describe the use of traditional method in teaching-learning done by alumni of Middle East, and (3) to describe the reasons of the use of traditional method in teaching-learning in Islamic education. This research was done using qualitative approach. The data collection method is in-depth interview, observation, and documentation. After doing the research, it can be summarized that the teaching-learning model of Islamic education for students or the Muslim community in Singapore are as follows: (1) Since the first Alumni Middle East prefer to use traditional methods (lecture). (2) Singapore classical scholars prefer to use traditional learning methods. (3) The public (including the lesson more) prefer the traditional method of lecture. (4) Singapore Islamic society prefers to acquire knowledge through lectures.. (5) The traditional method is a way to provide more knowledge than by using other methods. (6) The method of discourse is more suitable than other methods of teaching Islamic education in Singapore. (8) The typology of Singapore Islamic society prefer to hear and understand the learning materials using the lecture method. (9) It has been felt that the traditional methods of teaching Islamic education is more precise than other methods. (10) Alumni of the Middle East are reluctant to use other methods because of the experience gained during the knowledge he learned in a lecture model.

(C) 2017 AESS Publications. All Rights Reserved.

Keywords: Learning-teaching, Model, Islamic education, Madrasah, Mosque, Singapore.

Received: 21 June 2016/ Revised: 3 August 2016/ Accepted: 23 September 2016/ Published: 8 November 2016

\section{Contribution/ Originality}

This study is one of very few studies which have investigated about the condition of Islam and in particular Islamic education based on mosque in Singapore. The results of this study contribute knowledge in the form of information about Islamic education.

\section{INTRODUCTION}

Singapore is a secular state in Southeast Asia. A State inhabited by various ethnic groups. Most ethnic are Chinese, Malay, Indian and Western descent. Ethnic Malays only 14\% of the total Singapore population . Ethnic Malays in general is Muslim. Although the State Singapore is a secular state, but this state provide public space for all ethnicities and religions. Every religion is guaranteed and allowed to flourish in this country, including the Islamic 
religion. Although in Singapore there are public schools run by the government for all residents regardless of their ethnicity and religion, the government also allow each religious group has and set up special schools in accordance with their religion.

In Singapore, there is also a formal Islamic religious schools organized by the government, such as Al-Juneid madrasah. All the necessities and amenities supported by the government. Number of students, curriculum, and evaluation carried out by the government. The number of students is limited by the government so that not all Muslim societies can be accommodated in the school. It is intended by the government to balance the interests of Islamic student numbers by the number of pupils at the school held by other religions.

To accommodate the children of Muslim or Muslim parents can not enter formal Madrasah Islam, the Muslim community establish schools in the mosques either large or small in Singapore. Forms and models of school is not the same as the madrasah held by the government. However, school model is very attractive to the Islamic community and supported by the Muslim Malay ethnic. This kind of education is constantly evolving and is supported by the Singapore government and overseen by a panel formed by the government, namely the Assembly of Religious Islam (MUIS). The purposes of this research is to know:

(i) The characteristic of method in teaching-learning done by alumni of Middle East in Islamic education.

(ii) The use of traditional method in teaching-learning done by alumni of Middle East, and

(iii) The reasons the use of traditional method in teaching-learning by alumni of Middle East in Islamic education.

\section{LITERATURE REVIEW}

Malay society gasped and angry toward such sentiments. The local Islamic people are so concerned about the fate of six full-time madrasahs (which has 4000 students) and reiterated their stance that traditional Islamic education in schools must be maintained and should not be subject to the reforms the government (Mutalib, 2015). That the local Muslims know the early history of the madrasah in Singapore (Madrasah As-Sibyan and Madrasah Al-Iqbal was among the earliest to be established in Singapore, respectively in 1905 and 1908) and the struggle and sacrifice of their ancestors in maintaining madrasah school system, adding their concern over the government's draft.

A religious teacher not only teach the knowledge of Islam in the learning process, but also undertake other efforts that can help achieve the objectives of Islamic education. These efforts, among others, realized through the efforts of teachers of religion in fostering religious situation among educators and students, they are reflected in efforts to understand the teachings of the religion, the ingenuity of the students as well as live a simple and frugal, love for cleanliness, and soon realize and correct the error (Sanusi, 2013).

In his research, Ridhuan et al. (2014) explains that qualified teachers are those who are experts in the subject matter of knowledge and capable to manage personnel, props and classes effectively. Teachers who have a high level of professional competence to be able to produce students who are competent and able to adapt to changes in their environment. His research aims to examine the needs of teacher competence in the management of teaching and learning in schools based on expert opinion. Domain consists of creating atmosphere of teaching and learning to motivate students, able to manage the group's activities affectively to students, are able to control the behavior of students in the learning process, capable to manage learning outdoor activities involved, was able to encourage students to present projects or group work, able to clearly communicate with students during the learning process and is able to connect the experience with knowledge in the learning process. These findings suggest that the competence of managing in teaching and learning and all the elements necessary to assess the competence of teachers based on the consensus of experts.

Fathiyah et al. (2012;2013;2014) does research about understanding and experience in implanting deed (worship) as an element in teaching practice nominally as a teacher of Islamic education. Her research uses a qualitative method. In-depth interviews, and observation and document analysis undertaken for the purpose of collecting the data. The results of this research indicates that teachers understand the word element refers to the concept of worship 
that needs to be done in line with sharia and need to be practiced in our lives all day. Meanwhile experience in implanting the element of worship of teachers is done through demonstrations, practices consistent, monitoring, advising and highlights the importance of worship. In conclusion, this research illustrates that the 'worship' as an element to be understood and applied by teachers. However, some aspects may need to be increased. Finally, the study also discusses the implications and suggestions for future research.

Hanani (2013) in his research about "Elements to Recognizes Students in Teaching" concluded that generally teachers must recognize the students' skills in all aspects and this is one of the elements of effective learning as an excellent teacher. It also includes one of the main components of Pedagogical Content Knowledge. Thus, Islamic Education Teachers very good to know accurately about their students that is considered as the most important concept in the teachings of the Prophet Muhammad. A primary goal of this qualitative research was to explore the extent of the good teacher of Islamic education in terms of their knowledge to their students, especially in the chapter of worship. This research material is researched to a female teacher who had taught for ten years as a teacher of Islamic education is very good. This research found that teachers know their students on five key characteristics, namely the student's background, learning problems, characteristics, academic level and motivation. In conclusion, the student teacher's knowledge has pushed to plan and carry out the effective teaching and learning process.

AIiff and Yusraini (2014) in their research entitled "A Study on The Strategies and Practice of Teaching Among Trainee Teachers During the Teaching Training" identify the principles and theories of learning in use made by teachers when selecting teaching approaches and the extent to which teachers participating coaches diversify teaching methods to apply effective teaching strategies. This research is a form of the servey to 30 trainee teachers in Islamic education in the Faculty of Education, Universiti Kembangsaan Malaysia. The instrument used in this study is a questionnaire form. Data were analyzed using the statistical package for social sciences version 17 software to find the results, the percentage and frequency. The findings showed that trainee teachers still use learning approach of Islamic Education teacher-centered. In addition they often adopt the method of inductive and behavioral learning theory. In conclusion, teaching approaches and strategies undertaken by trainee teachers should be improved to give a good effect on the quality of teaching. Besides, also some suggestions about teaching strategies also implemented.

According to Haskell (2010) each teaching learning process must be included with the transfer of knowledge that is used and a long-standing theory for these displacements were considered by Haskell needs to be renewed. There are seven models of Transfer of Learning theory and four there of is as the primary model. Below researchers brought a model of transfer of learning that is relevant to this research as follows, namely the model Displacement Formal Discipline (Formal Discipline Model of Transfer). Model of this kind gives means every learning it, no matter what kind of subjects are taught and delivered to learners there are similarities and can be used in any context though. Logic depths or discipline or structure of the materials studied by learners it will automatically move to the reasoning. According to Haskell, this model is more to classical or ancient, as an example, what is learned by the student who submitted it automatically he can and can apply what they learn through the teacher.

But according to Haskell is not all apply for using a disciplined approach is considered old-fashioned, even though there are so-called critical thinking program that supposed that the transfer will occur by teaching thinking skills. According to Haskell that are only assumption mere, what people crowded understand him is an assumption that is a failure, because what actually learned by learners undue he gets and can convey the original what is learned in the past and is not that easy which assumed by most people. But Haskell viewed from different angles that beautify and improve the theory of this type of model.

Turns Haskell sees how understood most people on the theory of the classical is what is learned by learners can be applied as well to solve the problem all day, but it all really is not applicable, and according Haskell that teachers can not be sure the learning that learners can not understand it, but according Haskell teacher was able to show what is learned by students that he should not be able to understand and accept fully even teacher merely capable of providing guidance, instructional shows, street or ropes only. In this case, Haskell sees that learning and development 
of learners it depends on individual himself. Haskell then said that improper use of the feeling it is a pre-requisite for the entry into force of the transfer of learning, whether the effective component can be a source of history and foundation of formal discipline model? Then Haskell said that the discovery of the theory of transfer of learning on these observations, it should be noted that displacement models indicate that there are 7 domains how they apply transfer of learning in the education of students as the following: Transfer of learning is inherent only applies to certain disciplines only.

(i) Transfer of learning occurs with the recognition element identic between two stimuli that exist in concrete reality.

(ii) The Transfer of learning goes related to what happened to a specific event (incidental learning).

(iii) The Transfer of learning happens with the stimulus generalization.

(iv) The Transfer of learning occurs with the induction of cognitive schema.

(v) The transfer of the learning that goes with being promoted by the image and usability metacognitive strategies.

(vi) The Transfer of learning it actually belonged to the characteristics of individual learners.

\section{METHOD}

This research use a qualitative approach that describes the micro phenomena. This research was conducted in some madrasah in Singapore namely Madrasah Al-Junied Al-Islamiah, Madrasah Al-Sagoff Al-Arabiah, Madrasah Wak Tanjung Al-Islamiah and Madrasah Al-Ma'arif Al-Islamiah. The number of teacher of madrasah who are alumni from Middle East in Singapore is twenty persons. The informants of this research is nine teachers who teach at this madrasah. The informants for teachers were chosen by using purposes sampling technique. Besides, students Malay descendants who were studying in Islamic education based on Mosque. This research use the methods of data collection; observation and in-depth interviews. After the emic data collected then be analyzed qualitatively to describe and interpret the data. Interpretation of this research is done through a process of heuristic as developed Leech (1993); Miles and Michael (1984). With this process the data is interpreted by using the propositions that exist in the minds of researchers and supported by field notes and data from studies of documentation and interviews.

\section{RESULTS AND DISCUSSION}

Implementation of traditional learning methods at the school conducted by the cleric at the madrasah in Singapore based on field research is as delivered by the informant research. First Informan, 52 years old, a graduate of University of Kuwait. He has devoted itself to the madrasa al-Junied al-Islamiyah. He was included senior ustadz and has many devoted himself to the madrassa education for 25 years so he deserves to be a source of information. He says:

I have for years as a religious scholar of Islamic religious education in this country and I think the implementation of Islamic religious education in Singapore is not much change. The alumni of the Middle East including I prefer to use the method of "one way traffic" that is as directions in teaching the lesson. Over the years I use such this methods, I used to be in college or studying in the Middle East through in that way (traditional). Method one direction (traditional) is suitable for science teaches religious education. Lectures are more suitable for students of Islam in Singapore because since the first of this method has been carried out by the classical scholars at the time of the kingdoms of the Malay ground. In addition, conditions of students in Singapore been accustomed to facing that way. Nearly the alumni of the Middle East have the same character in both teaching and learning process in formal education and also non-formal education. What has been delivered by the informant mentioned above illustrates that traditional methods be alternative method most preferred by the cleric alumni of the Middle East. This statement is similar to what was spoken by the second informant, 48 years old, a graduate of University of Umm Al-Quran Makkah. He has been a teacher for 20 years in the madrasa alJunied al-Islamiyah, as follows: 
Seems to have become a habit for the preachers alumni of the Middle East when teaching in their madrasas using traditional methods (lectures). This is understandable because the sciences that they can is through such methods. It seems that I can not leave this method because I consider the implementation of Islamic religious education is identical to the propagation of Islam itself. In Islamic teaching lecture method is most suitable. With this principle it is often the alumni of the Middle East does not distinguish methods in delivering public lectures to teach religious education in the official class. I myself had the principle that the lecture method is the most suitable method to teach Islam or the Arabic language education in madrassas Singapore. Singapore Muslims context are the ones who need the science in a way to hear, see, and memorize. Other learning methods (such as: Frequently asked questions, assignments, etc.) are rarely used because it is less suited to the conditions of students in Singapore

For complete information on the implementation of the above-mentioned learning methods, researchers are not getting enough data. To that end, researchers continued to interview with another informant about the same problems. Third informant, 40 years old, a graduate of University of Tripoli, Libya. He has taught for 20 years at the madrasa alMaarif al-Islamiyah. He was included selected informants and researchers the opportunity to confirm the implementation of learning methods. He says:

As a cleric, I have been teaching Islamic education enough time in this madrasah. In the execution of the learning I always use the traditional lecture method. Lecture is a suitable method in teaching Islamic education or Arabic language to the learners for both young or older students Singapore. In general, people Singapore prefer the lecture method. They like to hear but do not want to ask. Actually, the cleric-ustadz alumni of the Middle East want to also use a mixture of methods (such as question and answer, assignments, discussions, home work and others). However, it is less suitable for students here (Singapore) for the typology of students in madrassas Singapore prefer to gain knowledge in a way to hear the lecture .So I need to inform you here that there are differences in the methods used in the process of learning and teaching for the teacher or cleric alumni of the Middle East than other graduates. Ustadz alumni of other universities use mixed methods because they gain knowledge with other methods.

From the above information, in fact researchers gain data that is significant enough that the traditional methods used by the cleric alumni of the Middle East in madrassas Singapore indeed well suited to the conditions and character of students Singapore. Fourth informant also not argue if the preachers of alumni of the Middle East have the desire to use methods other, but returned on the grounds that pattern of society Singapore who like to listen and do not want to ask, so methods FAQ rarely used in teaching and learning in madrasas.

One of the other informant namely the fifth informant 40 years old, a graduate of University of Azhar, Egypt. He has devoted himself as a teacher at the madrasa al-Saqoff al-Arabiah for 20 years, was also asked to comment on the implementation of traditional methods in madrasas in Singapore as follows:

Malay Islamic community in Singapore have different characteristics or typology with Islamic communities in other countries. Islamic social relationships are built on the basis of familiarity of Islam. As minority Islamic groups in the midst of the secular state, the Islamic community really keep Islam from all its aspects. One way to strengthen Islam for Muslims in Singapore is to plant early Islamic education for children. Planting Islam in children starting from kindergarten to madrasah aliyah. Society expects students at the school have enough Islamic knowledge and strong. Propaganda methods applied in the madrasah is quite important for the spread of Islamic sciences or Islamic education. This is the reason for the preachers alumni of the Middle East, including my maintain the traditional methods. I prefer to use the traditional method is because it can gives a lot of science as much as the students need. Likewise, I see that students at madrasas in Singapore prefer by way of lectures than the other methods

Regarding the important information about relationship between the characteristics of Islamic society by reason of the use of traditional methods (lectures), according to him there is no difference between Islamic education with 
lectures or preaching Islam so that he thinks there are more important in the learning process of Islamic education than with traditional methods (lectures). Second, for the establishment and cultivation of good Islamic education for students in madrassas and also the teaching community forums is a better fit by using traditional methods.

To obtain other data on the implementation of traditional methods of teaching Islamic education, the researchers conducted interviews with the sixth informant, 55 years old, a graduate of the University of Tripoli, Libya, and has served on the madrasa al-Maarif al-Islamiya for 20 years, Regarding the teaching methods of Islamic education, he said the following:

I have served on this madrasah for approximately 20 years. My Ustadzs and another teacher dedicates to the educational institutions feel more comfortable using traditional learning methods (lecture) because I saw there is no difference of method in teaching the subject to children or students at the school with the general public. For me the learning methods of Islamic education is more suitable using lecture than other modern methods. During my teaching here, none of this students of this institution who complain about the methods I use in teaching the Islamic religion. I get the impression that almost ninety cent ustadzs in Singapore still use traditional ways in teaching Islamic education.

Statement of the informant above confirmed the information mentioned .To corroborate the statements mentioned above, the researchers also conducted an interview with the seventh informant, He was included senior cleric in the institute. When he was interviewed about the implementation of the teaching methods used by the alumni of the Middle East in the teaching of Islamic religious education in madrasas in Singapore, he confirmed that almost all of the Middle East alumni use the way traditional methods.

I have been living in Singapore and for me one of the cleric graduates Middle East is very aware of the methods or learning techniques used by alumni of the Middle East in the learning process either in madrasah full time or also weekend. This was done probably because they have the experience of the study period in the Middle East where many ustadz use the lecture method (traditional). Besides the subject of religious education is more appropriate to use traditional methods (lectures) rather than modern methods that exist today. That does not mean that modern methods are worse than traditional methods. The traditional method seems more appropriate to use in the learning process of the Islamic community that has typology of Singapore society that prefer to hear and understand a subject that is delivered by means of lectures or traditional approaches. I Never did use any other method that is both modern as FAQs, class discussions, assignments, and presentations, because in general they (students) are not responsive and properly and satisfactorily. Therefore I use traditional methods (lectures).

In line with the above statement, the eighth informant, 26 years old, a graduate of the University of al-Azhar, Egypt. He is including a relatively junior teacher. He served for six years on a madrassa Wak Tanjung al-Islamiyah, states that there is a tradition or heritage of the ways Islamic studies in Singapore left by sheiks and Habib-Habib in the Islamic empire since before Singapore as independent state. It is delivered in an interview as follows:

I am including a cleric who always wanted to change the way teaching Islamic education in Singapore. However I am facing difficulties due to the condition of students not in accordance with what we want. The nature and character of students in Singapore very different to Indonesian students. Students in Singapore never do things that involve violations of moral, ethical, irreverence and violations of applicable law. This is caused by the model of Islamic education is embedded in the community since the sheiks and Habaib in Singapore. These conditions are continued by the younger generations of Islam until now. The means used by the sheiks and habaib in the past in instilling good values and Islam is by lecture. Lectures on today can be regarded as the traditional learning methods because now many modern methods are considered more good and superior compared to traditional methods. Yet still, the alumni of the Middle East maintain a traditional way because more appropriate to the character of the Malay Muslim community in general. These are the reasons that the 
traditional method is still considered more mainstream and is suitable for students in the madrasas in Singapore.

To reinforce the reasons for the importance of using traditional methods submitted by the informant above, the researchers conducted interviews for last informant in this study, namely the tenth informant, a cleric aged 26 years, alumni of the University of Al-Azhar, Egypt and has served as cleric for 6 years, states the following:

Ustadz or cleric alumni of Middle Eastern (Arab, Egypt, Libiya, Syria, Kuwait) have the same experience intake into science. Almost all universities in these countries use the system and the same way in conveying knowledge to students. Almost all of the more dominant science delivered by way of lectures. So it is not surprising that the alumni are accustomed to teaching by using traditional methods. This strong influence brought home to their respective countries including Singapore so that when they become teachers or cleric will continue to use traditional methods. The second reason is the attitude and character of the Malay Islamic nation in Singapore very supportive, which is generally in the learning process, either in the mosque institution or in madrassas full time, they are more like the way the lecture method (traditional). So according to my habit of alumni of the Middle East using the traditional method is the hallmark everywhere. They are as reluctant to use new methods are more modern in the learning process of the Islamic religion.

From some of the information or data obtained in the above, it can be concluded that the implementation of the traditional methods used by the alumni of the Middle East in the learning process in the madrasas in Singapore caused by the first two things because habits experienced by the alumni during gaining knowledge while studying in the Middle East. They habit use that method to acquire knowledge. Almost all universities in the Middle East rely on traditional methods in teaching and learning.

Second, Islam Singapore Malay society is a society that has a history of Islam since the time of Islamic kingdoms. The tradition of Islamic kingdoms influence the attitudes and traditions to the general public. It is influenced by the tradition inherited by Shaikh and the habaib. Sheikh and Habaib are people who have a high Islamic character. Their ways to instill piety, submission to the teacher and the people who have knowledge using means the traditional way (lectures).

To prove whether all the data obtained from interviews with alumni is correct, researchers conducted observations in some classes was going learning process. Researchers followed and watched the process and see what teachers do in presenting Islamic education material and Arabic language. The researchers note that in some of the classes visited, teachers use the lecture method in teaching and learning in the classroom.

From the observations above show that there is a match between the data obtained from the interviews with observations done. With the data obtained through this observation it can be concluded that the teachers alumni of the Middle East in the learning process using traditional methods such as lectures.

\section{CONCLUSION}

In accordance with the objectives of this study that is describing (1) the implementation of traditional methods of teaching Islamic education in Singapore, (2) the importance of the traditional methods of teaching learning of Islamic Education, and (3) the reasons the use of traditional method in teaching-learning by alumni of Middle East in Islamic education, so based on data obtained and used descriptive analysis can be summarized as follows:

5.1. From the above analysis, it can be summarized based on the substance of the statements delivered it was concluded that the implications of Islamic education learning method for students or the Muslim community in Singapore are as follows: (1) Since the first Alumni Middle East prefer to use traditional methods (lecture). (2) scholars Singapore classical prefer to use traditional learning methods. (3) The public (including the lesson more) prefer the traditional method of lecture). (4) Society Singapore prefers to acquire knowledge through lectures. (5) Since the first Alumni Middle East prefer to use traditional methods (lectures). (6) The traditional method is a way to provide more knowledge than by using other methods. (7) The method of discourse is more suitable than other 
methods of teaching Islamic education in Singapore. (8) The typology of Islamic society Singapore prefer to hear and understand the learning materials using the lecture method. (9) It has been felt that the traditional methods of teaching Islamic education is more precise than other methods. (10) Alumni-alumni of the Middle East are reluctant to use other methods because of the experience gained during the knowledge he learned in a lecture mode.

5.2. Meanwhile some reason the use of traditional methods in teaching Islamic religious education are as follows: (1) Middle East Alumni assume that the character of Singapore's Malay community prefers traditional methods (lectures). (2) A modern method is considered by them unsuitable for people Singpore in studying Islamic education. (3) The modern method is considered by them are not suitable for the people of Singapore in studying Islamic education. (4) Middle East Alumni prefer traditional methods because the background when obtaining knowledge at the time of learning in the Middle East. (5) There are efforts to change the method but Singapore society prefers lecture method. (6) The use of traditional methods is more relevant to learning Islamic education. (7) Realizing that modern methods can also be used in teaching Islamic education but more suitable by using traditional methods.

\section{Funding: This study received no specific financial support.}

Competing Interests: The authors declare that they have no competing interests.

\section{Contributors/Acknowledgement: All authors contributed equally to the conception and design of the study.}

\section{REFERENCES}

Aliff and Yusraini, 2014. A study on the strategies and practice of teaching among trainee teachers during the teaching training. Journal of Islamic Education, 2(1): 1-6.

Fathiyah, M.F., S. Asmawati, A.M. Lukman and R. Samsilah, 2012. Perkembangan sekolah islam swasta dan sumbangannya kepada sistem pendidikan negar a. Paper Presentation at the 3rd International Conference on Islamic Education 2013 (ICIED 2013) on 6-7 April 2013 at Pusat Latihan Esset KWSP, Kajang, Selangor.

Fathiyah, M.F., H.A. Nor, H. Azimi and A.M. Lukman, 2013. Pemahaman dan pengalaman guru pendidikan islam menerapkan elemen amalan dalam pengajaran. Online Journal of Islamic Education, 1(1): 1-12.

Fathiyah, M.F. and S. Asmawati, 2014. Private islamic primary school teachers commitment in human capital development in Malaysia. Mediterranean Journal of Social Sciences, MCSER Publishing, Rome-Italy, 5(27): 766-773.

Hanani, N., 2013. Guru Cemerlang pendidikan islam. Online Journal of Islamic Education, 1(2): 18-30.

Haskell, R.E., 2010. Transfer of learning, cognition, instuction and reasoning. UK: Academic Press.

Leech, G., 1993. Prinsip-prinsip pragmatik. (Ter. M.D.Oka). Jakarta: Universitas Indonesia Press.

Miles, M.B. and H.A. Michael, 1984. Qualitative data analysis; a sourcebook of new methods. Beverly Hill: Sage Publication Inc. Mutalib, H., 2015. Melayu Singapura; sebagai kaum minoriti dan muslim dalam Sebuah Negeri global. Singapore: NUS Press.

Ridhuan, M.M.J., S. Shariza and I.Z.K. Mohd, 2014. Kompetensi guru terhadap pengurusan pengajaran dan pembelajaran: Suatu pendekatan teknik fuzzy delphi. Jurnal Kepimpinan Pendidikan, 1(3): 77-88.

Sanusi, H.P., 2013. The role of teachers PAI in the development of Nuance religious schools. Ta'lim Journal of Islamic Education, 11(2): 23-45.

\section{BIBLIOGRAPHY}

Hanani, N.H., A.C.N. Mohd and T.A. Halim, 2013. Element Mengenali Murid dalam Pengajaran Guru Cemerlang Pendidikan Islam. Online Journal of Islamic Education, 1(2): 10-19. 